\title{
HAK ANGgOTA SERIKAT PEKERJA PERSPEKTIF HAK ASASI MANUSIA
}

\author{
Bahder Johan Nasution \\ Universitas Jambi, JI. Lintas Jambi - Muara Bulian KM. I 5, Muara Bulian Kota Jambi \\ bj_nasution1414@yahoo.com
}

\begin{abstract}
The concept of rights and freedom as well as their guarantee cannot be separated from a system of value and principle that inspires them. In a democratic society, right and freedom are inherent in human, a guarantee of both, and their law enforcement, cannot be separated. The rights include rights to form a union and association. For workers this rights and freedom are implemented in the form of a labor union that serves as a means to make a political bargain with employers. The union is also important instrument for workers in fighting for their normative rights.
\end{abstract}

Keywords: Trade union right, freedom of association.

\begin{abstract}
Abstrak: Konsep mengenai hak dan kebebasan maupun mengenai jaminannya tidak dapat dipisahkan dari sistem nilai dan asas yang mengilhaminya. Dalam suatu masyarakat demokratis, hak dan kebebasan yang melekat pada manusia, jaminan terhadap hak dan kebebasan itu, serta penegakannya secara hukum membentuk suatu kesatuan yang tidak dapat dipisahkan. Bagi pekerja hak dan kebebasan ini diimplementasikan dalam bentuk serikat pekerja yang berfungsi sebagai sarana untuk melakukan tawar menawar dengan pengusaha dan sebagai instrument dalam memperjuangkan hak-hak normatifnya.

Kata Kunci: Hak serikat pekerja, kebebasan berserikat
\end{abstract}

\section{Pendahuluan}

Dari segi istilah konsep hak merupakan terjemahan dari "right" dalam bahasa Inggris, sedang dalam bahasa Jerman istilah hak sama dan sebangun dengan istilah hukum yaitu "recht", hal yang sama juga ditemukan dalam literatur hukum Perancis yaitu "droit". Di dalam literatur hukum Belanda istilah "recht" di bagi menjadi dua yaitu "objectief 
recht dan "subjectief recht". "objectief recht" berarti hukum karena sifatnya umum dan mengikat semua orang, oleh karenanya ia dipandang sebagai peraturan atau norma, sedang "subyektief recht" berarti hak dan kewajiban, namun demikian, biarpun pengertian "subyektief recht" menunjuk pada hak dan kewajiban, akan tetapi pada umumnya yang dimaksud dengan "subyektief recht" hanya hak semata-mata, tidak termasuk kewajiban.

Dalam istilah hukum Jerman dan Perancis, Pembedaan antara hukum dan hak dilakukan dengan menggunakan prase "objectives recht" dan "subjectives recht" untuk istilah hukum Jerman, serta "droit objectif dan droiit subjectif" untuk istilah hukum Perancis. "objectives recht atau dorit objectif (hak obyektif) diartikan sebagai hukum, sedangkan "subjectives recht: atau "droit subjectief" (hak subyektif) diartikan sebagai hak. Istilah hak di sini didefinisikan sebagai kehendak atau kepentingan. Jadi hak adalah kepentingan yang dilindungi oleh hukum ${ }^{2}$. Senada dengan itu, Paton mengartikan hak sebagai: the right of contract arise directly from a justice act. Other rights are granted by the law, whether the person bound by duty consent or not ${ }^{3}$.

Pengkajian tentang hak, ruang lingkupnya tidak hanya dalam konteks hukum, tetapi juga dalam konteks moral. Jadi sifat hak tergantung dari sifat hukum yang mendasarinya. Apabila suatu hak diperoleh berdasarkan hukum negara, hak tersebut merupakan hak hukum. Definisi hak hukum sebagai suatu kepentingan yang dilindungi hukum, atau suatu kehendak yang diakui, baru dianggap sebagai hak hukum apabila ada jaminan dari hukum positif. Hal ini berarti bahwa hak itu diberikan oleh hukum positif.

\footnotetext{
Victor L. Leander, Kamus Belanda Indonesia, (Jakarta: Mutiara, 1978), 128.

2 Sudikno Mertokusumo, Mengenal Hukum, (Yogyakarta: Liberty, 1996), 41.

${ }^{3}$ G.W. Paton, A Tex Book of Jurisprudence, (London: Oxford at the Clarendom Press, 1955), 372.
} 
Sebaliknya, hak-hak yang dimiliki manusia berdasarkan martabatnya sebagai manusia dan bukan karena diberikan oleh hukum positif atau oleh negara disebut dengan kebebasan berserikat.

Implementasi kebebasan berserikat bagi pekerja, dalam bentuk serikat pekerja awal mulanya didirikan di Inggris pada tahun 1864. Sejak saat itu serikat pekerja terus berkembang baik pada tingkat nasional, regional maupun internasional. Puncak perkembangannya terjadi pada tahun 1919 ketika berdirinya "International Labour Organization" (ILO) sebagai organisasi perburuhan internasional. Pada konferensi umum ILO di Philadelphia diterima deklarasi ILO yang menegaskan bahwa prinsip-prinsip deklarasi dapat diterapkan di seluruh dunia.

Prinsip pokok organisasi perburuhan internasional didasarkan pada perlindungan dan penghormatan terhadap kebebasan berserikat, prinsip keadilan sosial dan penghapusan kemiskinan. Jika ditelaah dari sejarah perkembangannya, ILO sebagai salah satu badan PBB berbeda dengan badan-badan lainnya. Perbedaan itu terlihat terutama dari hal-hal yang berhubungan dengan prinsip keadilan sosial. Perbedaan itu dapat dilihat dari mukaddimah konstitusi ILO yang dimulai dengan kalimat "Whereas Universal and lasting peace can be established only if it is based upon social justice"4. Dari pernyataan tersebut terlihat begitu kuatnya komitmen organisasi tersebut terhadap pencapaian keadilan sosial sebagai tujuan.

Ide merumuskan keadilan sosial dalam konstitusi ILO ini tampaknya diilhami atau mendapat pengaruh yang kuat dari Mashab Keynes yang membangun teorinya

\footnotetext{
${ }^{4}$ Periksa Mukaddimah Konstitusi ILO dimulai dengan kalimat: Karena perdamaian dunia yang abadi hanya dapat terbentuk jika didasarkan pada keadilan sosial. Baca juga lan Browlie, Doumen-dokumen Pokok Mengenai Hal Asasi Manusia, terj. Beriansyah, (Jakarta: UI-Press, 1993), 227.
} 
berlandaskan hukum-hukum ekonomi, yaitu mengenai tercapainya equilibrium dengan full employment dan full production dengan bantuan campur tangan negara. Di dalam teori keadilan Aristoteles tentang keadilan distibusitf menghendaki adanya keterlibatan negara secara exstensif memberikan kepada warga negara apa yang menjadi haknya yang dikenal dengan sebutan suum quique tribuere. Dalam perkembangannya kemudian konsep keadilan komutatif juga memerlukan campur tangan negara dalam banyak hal agar tercapai keseimbangan dan persamaan, misalnya dengan pengaturan dengan kekuatan-kekuatan ekonomi yang tidak seimbang yang menimbulkan persaingan, pemerasan dan kejahatan di bidang perekonomian.

Dalam hal ini dituntut adanya tindakan "rendering to everyone his own". Oleh karena itu harus diserahkan segala sesuatunya kepada setiap orang apa yang menjadi haknya. Mengenai istilah kepada setiap orang tersebut di dalamnya terkandung makna tentang penghormatan terhadap kebebasan berserikat sebagaimana dikemukakan oleh Drummond 5 bahwa keadilan mengandung "certain equality" yaitu persamaan derajat diantara sesama manusia. Jadi keadilan telah memberikan hubungan yang seimbang diantara sesama manusia serta memberikan apa yang menjadi haknya dan menjadi kebebasan diantara mereka yang ingin memperoleh keadilan tersebut.

Dalam konteks ini untuk mensintesakan pengertian keadilan dengan konsep penghormatan terhadap kebebasan berserikat sebagai bagian dari hak asasi manusia, adalah bahwa hak yang merupakan bagian dari suatu keadilan tumbuh dari konsep penghormatan terhadap hak asasi manusia. Penghormatan itu merupakan sesuatu yang melekat dengan hakekat diri dan pada akhirnya sesuatu

${ }^{5}$ William Frederick Drummond, Social Justice, (Milwaukee: The Bruce Publishing Company, 1995), 14. 
yang berhubungan dengan tujuannya yang abadi, dalam hal inilah hak alamiah atau natural right berasal dan secara sah dipertahankan sebagai miliknya, hak tersebut dapat dimanfaatkan untuk memenuhi kebutuhan dan kebahagiaan hidupnya, baik yang bersifat temporer maupun yang abadi, hal ini mengandung pengertian bahwa penentuan hak seseorang sangat terkait atau sangat tergantung pada pengakuan orang lain.

Lebih jauh dari itu karena manusia pada dasarnya secara alamiah merupakan makhluk sosial yang hidup bersama dengan manusia lainnya serta mempunyai kehormatan dan hak yang sama, maka hak alamiah yang menjadi miliknya itu harus dibatasi. Batasannya adalah hak dan kebebasan orang lain, sehingga pada setiap hak yang timbul selalu muncul kewajiban untuk menghormatinya secara timbal balik, sehingga dengan demikian sebenarnya equal rights mean limited rights setiap orang tidak boleh menggunakan haknya sedemikian rupa sehingga mengganggu orang lain, akan tetapi manusia sebagai makhluk sosial tentu saja tidak bisa disibukkan dengan halhal yang bersifat menggunakan haknya semata-mata, manusia harus pula bekerjasama dengan sesamanya untuk membangun sesuatu yang baik dan berguna untuk kehidupan bersama.

Dari apa yang diuraikan ditas permasalahan yang akan dibahas dalam tulisan yang singkat ini dapat dirumuskan sebagai berikut:

1. Kebebasan Berserikat bagi Pekerja Sebagai Jaminan Penghormatan Terhadap Hak Asasi Manusia

2. Kebebasan Berserikat Bagi Pekerja Sebagai Instrumen Perjuangan hak Normatif Pekerja 
Perkembangan Kebebasan Berserikat bagi Pekerja sebagai Jaminan Penghormatan terhadap Hak Asasi Manusia

Keadilan yang dibangun dengan memperhatikan hak alami, kewajiban alami dan kewajiban sosial dari manusia yang hidup bersama itu, dapat dibagi berdasarkan penggolongan sebagaimana yang telah dinyatakan Aristoteles tentang keadilan komutatif dan keadilan distributif. Pada tiap bagian dari keadilan itu terbuka campur tangan penguasa agar manusia secara keseluruhan dapat menggunakan hak pribadinya tanpa melupakan kewajiban sosialnya. Dengan demikian unsur sosial dalam keadilan itu diterima dan dilaksanakan untuk kepentingan dan kesejahteraan manusia. Hal yang sama dirumuskan oleh Paul Sieghart ${ }^{6}$ yang menambahkan bahwa pembagian hakhak manusia bilamana berbenturan dengan hak-hak orang lain, harus dimusyawarahkan secara demokratis sehingga dapat diperoleh keputusan yang adil. Sebagai pedoman umum sudah ditentukan di dalam Declaration of Human Rughts 1948 pada pasal 29 yang menyatakan bahwa pembatasan hak dan kebebasan yang sama bagi individu untuk mencapai tujuan hidupnya, hanya dapat dilakukan sekedar untuk menjaga hak dan kepentingan orang lain, menjaga moralitas dan menjaga kesejahteraan umum dalam suatu negara yang demokratis. Pemikiran seperti ini melahirkan konsep bahwa pemerintahan demokratis dibangun di atas dua prinsip dasar yaitu: Pertama, prinsip yang menyatakan bahwa setiap orang mempunyai kedudukan yang sama (gelijkheid) tanpa memandang derajat dan status sosialnya. Kedua, prinsip yang menyatakan bahwa setiap orang mempunyai kebebasan dalam melaksanakan kehendak (vrijheid). Para pemikir seperti Plato, Aristoteles dan Polibiyus yakin bahwa bentuk

${ }^{6}$ Paul Sieghart, The Lawfull Rights of Mankind, an Introduction to the International Legal Code of Human Rights, (New York: Oxford University Press, 1996), 146. 
pemerintahan demokratis adalah produk dari siklus pemerintahan. Untuk itu dalam konteks pemikiran modern, pemerintahan harus dapat mengakomodasikan kepentingan bersama dan hal ini merupakan prinsip kesamaan. Selain itu itu pemerintahan juga harus menghargai bahwa setiap orang mempunyai kepentingan individu, yang berarti mengakui prinsip kebebasan.

Berkaitan dengan hal tersebut di atas, John Dewey dapat dipandang sebagai pemberi dasar filosofisnya. Bagi Dewey ${ }^{7}$ jantung demokrasi adalah suatu keadaan di mana pilihan manusia (kebebasan) merupakan pimpinan utama. Suatu masyarakat demokratis tergantung pada konsensus sosial dengan pandangan pada perkembangan manusia yang didasarkan atas kebebasan, persamaan dan partisipasi politik, namun demikian, suatu dilema yang menarik dalam demokrasi diajukan oleh Alexis De Tocqueville ${ }^{8}$ bahwa walaupun prinsip kebebasan dalam demokrasi membawa kemanfaatan lebih besar, namun keberadaannya terancam oleh prinsip kesamaan. Misalnya dalam prinsip ekonomi, kebebasan biasanya hanya dapat dinikmati dan dimanfaatkan oleh sekelompok kecil tertentu, sehingga mengorbankan prinsip kesamaan.

Bertolak dari kenyataan yang demikian ini, walaupun pemerintahan demokratis dibangun di atas prinsip kebebasan dan persamaan, namun tidak berarti bahwa demokrasi hanya berdasarkan prinsip kebebasan dan persamaan semata-mata. Demokrasi terkait erat dengan masalah kemanusian secara universal, karena konsep demokrasi bukan sekedar permainan kekuatan dari pihak yang kuat terhadap pihak yang lemah. Demokrasi lebih

7 John Dewey dalam Mc Golderick, D., The Human Rights Committe, (Oxford: Clarendom Press, 1999).

${ }^{8}$ Alexis De Tocqueville dalam Burkens, M.C., et.al. Beginselen van de Democratische Rechtsstaat, (t.t.: Tjeenk Willink Zwale, 1990). 
merupakan suatu konsep politik untuk memberdayakan seluruh kekuatan masyarakat untuk kepentingan kemanusiaan yang universal. Prinsip egalitarian menuntut bukan hanya "one man is one vote" namun menuntut kesamaan hak yang efektif dalam hidup yang layak sesuai dengan keingingannya sebagaimana dikemukakan oleh Macpherson9: What is essential in modern democratic theory? As soon as democracy is feen as a kind of society, not merely a mechannism of choosing and authorizing goverments, the equalitarian principle inherent in democracy requires not only one man one vote, but also one man equal effective right to live as fully human as the may wish.

Demokrasi mengenal norma etik, yaitu mendayagunakan potensi manusia untuk mencapai tujuan kemanusiaan. Emmanuel Kant menaruh perhatian terhadap kebebasan, persamaan dan kemandirian dan kaitannya dengan hak-hak dasar yang secara universal dimiliki oleh setiap orang, tentang hal ini dikemukakan oleh Meuwissen ${ }^{10}$ : Kant zelf erkent slechts een drietal grondrechten,... Vrijheid, gelijheid en zelfstandingheid. De overige grondrechten kunnen alle doarop worden tereggevoerd. Het recht op vrijheid heeft betrekking of the relatie tussen subject en staatsmacht...

Para pemikir liberal, senantiasa melihat bahwa kekuasaan itu sebagai perampasan terhadap hak-hak pribadi, sedang para pemikir radikal cenderung menghubungkan kekuasaan dengan pengurangan kebebasan seseorang, oleh karena itu kaum liberal selalu menuntut agar di dalam konstitusi dimuat secara rinci tentang kebebasan. Dukungan terhadap pandangan ini dapat dijumpai secara eksplisit dalam konvensi Eropa dan Amerika di mana ajaran partisipasi demokrasi, rule of law dan perlindungan terhadap kebebasan berserikat terjalin

9 C.B. Macpherson, Democratic Theory, (Oxford: Clerendom Press, 1973), 51.

10 Meuwissen, Grondrechten, (Utrecht: Spectrum, 1984), 139. 
erat satu sama lain. Dengan demikian pembatasanpembatasan hak tersebut sebenarnya bukanlah dimaksudkan sekedar membatasi atau mengurangi hak tersebut seperti anggapan kaum Marxis, akan tetapi justru untuk meneguhkan adanya hak individu tersebut karena bagaimanapun juga selalu terdapat konflik kepentingan di dalam menjalankan hak tersebut di tengah-tengah kehidupan masyarakat.

Jika ditelaah makna yang terkandung dalam mukaddimah konstitusi ILO, kemudian dikaitkan dengan pendirian ILO berdasarkan traktat verseiles dapat dipahami bahwa pendirian ILO merupakan respon kepedulian masyarakat internasional mengenai keadilan sosial dan standar perlakuan terhadap pekerja industri, karena pada waktu itu perang dunia pertama yang membawa banyak korban baru saja berakhir. Penetapan ILO sebagai salah satu badan khusus PBB pada tahun 1946, dapat dianggap sebagai awal mula ditetapkannya sistem proteksi terhadap hak ekonomi, sosial dan budaya. Untuk tujuan tersebut ILO telah mensponsori lebih dari 150 konvensi, antara lain menyangkut perbaikan kondisi kerja, pemberian libur, jaminan sosial dan hak berorganisasi bagi pekerja dan sebagainya.

Sadar akan nilai-nilai kemanusiaan yang telah dijamin dalam konstitusi, termasuk di dalamnya kebebasan berserikat, negara-negara berkembang seperti Indonesia, Thailand, dan Filipina berusaha mengkaji kembali hukum ketenagakerjaan masing-masing yang semula diambil alih dari hukum negara yang pernah menjajahnya. Lembagalembaga dan prosedur hukum disesuaikan dengan kebutuhan setempat. Perlindungan terhadap kebebasan berserikat dan perbaikan jaminan sosial semakin mendapat perhatian. Begitu pula halnya di negara yang industrinya sudah maju seperti Jepang, Korea, Taiwan dan Cina. Di 
Jepang misalnya dalam konstitusinya dimuat hak pekerja untuk berorganisasi dan berunding secara kolektif. Pasal 28 dari konstitusinya memuat ketentuan; "The rights of workers to organize and bargain and act collectively is guaranteed". Sebenarnya di negara-negara eropa sekalipun jarang negara industri, kecuali Jerman, Prancis dan Italia yang mencantumkan hak berorganisasi dan berunding bersama bagi pekerja dalam UUD-nya. Biasanya hak tersebut hanya dicantumkan di dalam undang-undang yang merupakan pelaksanaan dari UUD tersebut.

Di Indonesia, pengaturan serikat pekerja terkait erat dengan pergerakan kemerdekaan selama berlangsungnya pemerintahan Hindia Belanda. Sedang pengaturannya setelah kemerdekaan tidak terlepas dari pengaruh perkembangan politik di tanah air. Sehubungan dengan itu, kajian terhadap pengaturan serikat pekerja di Indonesia, dapat dibagi menjadi dua periode, yaitu periode sebelum kemerdekaan dan sesudah kemerdekaan. Tinjauan historis terhdap pengaturan kebebasan berserikat ini, bertujuan untuk memahami secara menyeluruh maksud pemerintah mengadakan pengaturan kebebasan berserikat dan sejauhmana keberadaan hak tersebut dilindungi dan dihormati sebagai kebebasan berserikat.

Selama berlangsungnya pemerintahan Hindia Belanda, kebebasan berserikat bagi pekerja tidak dapat digunakan dengan baik, perlindungan dan penghormatan terhadap hak tersebut tidak terlaksana sebagaimana mestinya. Namun demikian tidak berarti bahwa pengaturan kebebasan berserikat tidak dikenal pada masa pemerintah Hindia Belanda. Dari berbagai literatur diketahui bahwa penggunaan kebebasan berserikat yang diimplementasikan dalam bentuk serikat pekerja, sudah ada sejak akhir abad ke XIX. Pada waktu itu guru-guru yang mengajar di sekolah Belanda mendirikan organisasi serikat pekerja, akan tetapi 
karena organisasi ini didirikan oleh orang-orang Belanda dan bersifat eksklusif maka di dalam sejarah perkembangannya pergerakan serikat pekerja ini belum diperhitungkan.

Pengaturan kebebasan berserikat pada masa itu dimuat dalam ketentuan "Verenigings en Vergaderings- verordening Stb. 1919 Nomor 27 jo 561, yaitu peraturan tentang pelaksanaan kebebasan berserikat dan berapat sebagai mana yang diatur dalam pasal 165 Indische Staatsregering (UndangUndang Dasar Hindia Belanda). Peraturan ini dianggap sebagai ketentuan yang memberikan perlindungan dengan sungguh-sungguh terhadap penggunaan kebebasan berserikat, sebab menurut ketentuan ini untuk mendirikan perkumpulan termasuk serikat pekerja tidak memerlukan izin terlebih dahulu dari penguasa. Ketentuan pasal 1 mengatakan; untuk mendirikan perkumpulan tidak dimintakan, disyaratkan izin dari pemerintah. Pembuktian tentang ada tidaknya serikat pekerja, dalam praktek biasanya diharuskan untuk mencantumkan di dalam anggaran dasarnya ketentuan-ketentuan seperti maksud dan tujuan serta usaha-usaha yang dilakukan.

Dalam praktek ketatanegaraan, untuk membuktikan ada tidaknya serikat pekerja merupakan persoalan hukum, yaitu apakah serikat-serikat atau perkumpulan itu mempunyai badan hukum (rechtsspersoonlijk-heid) atau tidak? Sehubungan dengan itu, Stb. 1870 Nomor 64 yang mengatur badan hukum bagi perkumpulan warga negara yang tunduk pada hukum eropa menurut ketentuan pasal 8 ayat (1), perkumpulan yang tidak diakui sebagai badan hukum, tidak dapat melakukan tindakan dalam lapangan hukum perdata. Selain itu peraturan tentang perkumpulan di Indonesia (ordonantie op de Indonesische vereninging) menentukan bahwa pengakuan sebagai badan hukum, dimintakan kepada dan diberikan oleh Pengadilan Negeri di 
tempat kedudukan perkumpulan yang bersangkutan. Dalam praktek tidak banyak serikat pekerja yang berstatus sebagai badan hukum, antara lain hanya organisasi pengajar bangsa Belanda di Indonesia dan kongres buruh seluruh Indonesia.

Lahirnya pergerakan kebangsaan Boedi Oetomo pada tahun 1908, membawa konsekuensi terhadap perkembangan serikat-serikat pekerja menurut bidang usaha masingmasing. Serikat pekerja yang pertama terbentuk adalah serikat pekerja kereta api dan trem (Vereniging van Spoor en Tremwy Personeel), disusul kemudian perserikatan guru bumi putera, serikat pegawai pekerjaan umum dan sebagainya. Pada tahun 1912 dari serikat-serikat pekerja yang ada, Serikat Islam mendirikan serikat pekerja gabungan dan inilah gabungan serikat pekerja yang pertama di Indonesia.

Gagasan untuk menggabungkan serikat-serikat pekerja yang ada menjadi satu, muncul pada kongres perserikatan pegawai pengadaian bumi putera di Bandung pada tahun 1919. Gagasan ini pada mulanya mendapat sambutan baik dari peserta kongres, namun pada tahap perumusannya terdapat kemacetan karena tidak ada kesatuan pandang. Masing-masing serikat pekerja yang ada mempertahankan ide perjuangannya sesuai dengan pandangan idiologinya. Hal ini dipengaruhi oleh gerakan perjuangan kemerdekaan pada waktu itu yang dipelopori oleh tiga aliran politik, yaitu Nasionalisme yang dipelopori oleh Gerakan Boedi Oetomo, Islam yang dimotori oleh Serikat Islam dan Marxisme melalui gabungan Serikat Buruh Revolusioner yang didirikan oleh Semaun. Dari perkembangan ini terlihat bahwa pola gerakan pekerja pada waktu itu tidak dapat dilepaskan dari pengaruh gerakan politik.

Kebebasan berserikat bagi pekerja yang diimplementasikan dalam bentuk serikat pekerja, mendapat jaminan dan perlindungan secara konstitusional setelah 
kemerdekaan RI diproklamirkan. Perkembangan serikat pekerja mendapat perhatian yang besar dari pemerintah terutama pada masa berlakunya UUDS 1950. Pekerja diberi kebebasan seluas-luasnya untuk membentuk serikat pekerja. Hal ini dapat dilihat dari ketentuan Peraturan Menteri Perburuhan Nomor 90 Tahun 1955 tentang Pendaftaran Serikat Buruh yang sifatnya sangat liberal. Menurut ketentuan itu, untuk mendirikan serikat buruh cukup dengan memiliki anggaran dasar, susunan pengurus dan daftar anggota tanpa menyebut jumlah minimumnya. Adanya kemudahan ini menyebabkan banyak muncul serikat pekerja di berbagai sektor usaha.

Pada masa orde baru, usaha untuk mempersatukan semua organisasi pekerja dengan gagasan membentuk satu wadah perjuangan yang tergabung dalam Majelis Permusyawaratan Buruh Indonesia (MPBI) terwujud pada tahun 1969. Pada satu sisi berdirinya majelis ini merupakan langkah maju di bidang penggunaan kebebasan berserikat bagi pekerja dibanding usaha-usaha sebelumnya, namun pada sisi lain ternyata dalam perkembangannya organisasi ini belum mampu menanggulangi masalah-masalah yang menyangkut dengan kepentingan pekerja. Hal ini disebabkan lemahnya struktur organisasi dan kepemimpinannya. Akibatnya organisasi ini tidak mampu berbuat banyak terutama mengambil putusan yang penting dan prinsipil sifatnya.

Sadar akan lemahnya peran serikat pekerja yang tergabung dalam majelis tersebut, melalui suatu seminar yang diadakan oleh Majelis Permusyawaratan Buruh Indonesia pada tahun 1971, diupayakan perubahan dan penyederhanaan eksistensi serikat pekerja. Upaya yang dilakukan pada intinya meliputi dua hal pokok. Pertama, mengadakan perubahan terhadap gerakan serikat pekerja agar berfungsi sosial ekonomi; Kedua, menyederhanakan 
keormasan serikat pekerja supaya bisa berfungsi secara efektif dan efisien dalam memperjuangkan hak-hak pekerja.

Dalam upaya menyederhanakan organisasi serikat pekerja tersebut, deklarasi persatuan buruh seluruh Indonesia yang ditanda tangani 20 Februari 1973 dipakai sebagai pangkal tolak kelahiran Federasi Buruh Seluruh Indonesia (FBSI). Proses peleburan organisasi pekerja ke dalam satu wadah FBSI diperkuat dengan Keputusan Menteri Tenaga Kerja Transmigrasi dan Koperasi Nomor 286a Tahun 1974 tentang Pengukuhan FBSI sebagai satusatunya wadah serikat pekerja. Dalam Keputusan tersebut antara lain dinyatakan; Departemen Tenaga Kerja Transmigrasi dan Koperasi mengakui FBSI sebagai vaksentral di Indonesia dari hasil vaksentral-vaksentral lama. Kedudukan FBSI kemudian diperkuat dengan Peraturan Menteri Tenaga Kerja dan Koperasi Nomor Per01/Men/1975 tentang Pendaftaran Organisasi Buruh.

Jika ditelaah lebih lanjut, dikeluarkannya Keputusan Menteri Tenaga Kerja Transmigrasi dan Koperasi Nomor 286a/1974 jo. Peraturan Menteri Tenaga Kerja Transmigrasi dan Koperasi Nomor Per-01/Men/1975, mempunyai makna yang sangat penting bagi eksistensi dan perkembangan FBSI dikemudian hari, karena:

1. FBSI diakui eksistensinya sebagai wadah serikat pekerja, hal ini berarti FBSI memiliki hak hidup yang diakui oleh pemerintah.

2. Pengakuan bahwa eksistensi tersebut adalah hasil peleburan dari vaksentral-vaksentral lama, mengandung arti bahwa bersamaan dengan pengakuan itu, hilang pengakuan terhadap serikat-serikat pekerja yang lama, dan yang diakui hanya FBSI sebagai serikat pekerja yang baru dan merupakan satu-satunya wadah serikat pekerja. 
3. Karena Keputusan Menteri Tenaga Kerja Transmigrasi dan Koperasi Nomor 286a/1974 dinyatakan mempunyai kekuatan pendaftaran sebagaimana dimaksud dalam UU Nomor 21/1954 tentang perjanjian perburuhan, mengandung arti bahwa sejak dikeluarkannya surat tersebut FBSI dengan segenap perangkatnya adalah satusatunya organisasi yang diakui sah oleh pemerintah.

Pada sisi lain, pengakuan pemerintah terhadap FBSI sebagai satu-satunya wadah serikat pekerja, bertentangan dengan kebebasan berserikat. Hal ini dapat dilihat dari ketentuan bahwa kebebasan berserikat mendapat jaminan dalam hukum dasar, pembatasan terhadap penggunaannya hanya dapat dilakukan dengan undang-undang, bukan dengan peraturan lain yang lebih rendah. Dalam prakteknya, penekanan terhadap kebebasan berserikat bagi pekerja di luar FBSI seperti Serikat Buruh Sejahtera Indonesia (SBSI) dilakukan dalam bentuk penekanan politik dengan tidak mendapat pengakuan dari pemerintah, kegiatan dan usaha-usahanya dianggap merupakan perlawanan terhadap pemerintah.

Upaya restrukturisasi dengan mengadakan perubahan terhadap nama dan bentuk organisasi FBSI dilakukan dalam Kongres kedua di Jakarta 1985. Perubahan yang paling mendasar adalah bergesernya bentuk organisasi yang semula federatif menjadi unitaris, dan istilah buruh diganti dengan pekerja, artinya FBSI berubah menjadi SPSI, penggunaan istilah buruh sebenarnya bersifat netral yang merupakan terjemahan dari istilah "labor" atau "worker" dalam bahasa Inggris dan "arbeider" dalam bahasa Belanda. Akan tetapi karena konotasi istilah buruh telah menjadi kurang tepat sebagai akibat dieksploitir PKI, maka istilah buruh diganti dengan pekerja. Batasan mengenai istilah pekerja dituangkan lebih jelas dalam Undang-undang Ketenagakerjaan dan Undang-undang Serikat Pekerja. 


\section{Kebebasan Berserikat bagi Pekerja sebagai Instrumen Perjuangan Hak Normatif Pekerja}

Pengaturan hukum dan penerapan kebebasan berserikat bagi pekerja sudah merupakan atau menjadi standar yang essensial bagi ILO. Jaminan terhadap kebebasan berserikat dan perlindungan hak untuk beroganisasi yang diatur dalam Konvensi ILO Nomor 87 tahun 1948 dan Konvensi ILO Nomor 98 tahun 1949, tentang hak untuk berorganisasi dan berunding bersama mengandung pengertian bahwa setiap pekerja bebas membentuk serikat pekerja sesuai dengan keinginannya atau bergabung dengan serikat pekerja yang sesuai dengan pilihannya. Kedua konvensi tersebut telah diratifikasi oleh pemerintah Indonesia, sehingga tidak ada alasan untuk tidak memberi kebebasan bagi pekerja menggunakan haknya untuk berserikat sebagai bagian dari asasi manusia.

Ratifikasi merupakan pengesahan yang terakhir dan mempunyai fungsi mengikat perjanjian, demikian pendapat Oppenheim ${ }^{11}$ dalam bukunya mengatakan: Ratification is the term for the final confirmation given by the parties to an international treaty concluded by their representatives. Although a treaty is concluded as soon as the mutual consent is manifest for acts of the duly authorised representatives, its binding force is, as a rule, suspended till ratification is given. Senada dengan itu Strake mengatakan sebagai berikut: Treaties go under a variety of names, some of which indicate a difference in procedure or greater or a lesser degree of formality. Thus besides the term "treaty" itself the following titles have been given: $(r)$ Convention ..... etc. ${ }^{12}$

'I. Oppenheim, International Law, (New York: Oxford University Press, 1947), 813.

12 J.G. Starke, An Introduction to International Law, (Berkley and Los Angles: University of California, 1954), 295. 
Dilihat dari sudut pandang kebebasan berserikat sebagai bagian dari hak asasi manusia maksud dari konvensi tersebut adalah:

- Menjamin kebebasan pekerja untuk menjadi anggota atau tidak menjadi anggota serikat pekerja.

- Melindungi pekerja terhadap campur tangan pengusaha dalam hal-hal yang berhubungan dengan serikat pekerja.

- Melindungi serikat pekerja terhadap campur tangan pengusaha dalam pendirian, cara kerja serta cara mengurus organisasinya, khususnya mendirikan organisasi di bawah pengaruh majikan atau yang disokong dengan uang atau cara lain oleh pengusaha.

- Menjamin penghargaan hak berorganisasi.

- Menjamin perkembangan serta penggunaan badan sukarela untuk mengatur syarat-syarat dan keadaankeadaan kerja dengan kesepakatan kerja bersama.

Pengaturan kebebasan berserikat yang diimplementasikan dalam bentuk serikat pekerja, di dalamnya terkandung hak (right) yang antara lain meliputi:

- hak membuat anggaran dasar dan anggaran rumah tangga secara mandiri;

- hak memilih wakil organisasi secara bebas tanpa tekanan atau campur tangan pihak lain;

- hak mengorganisasikan kegiatan administrasi dan aktivitasnya secara bebas dan mandiri;

- hak membuat program kerja organisasi;

- hak untuk bebas dari campur tangan pemerintah dalam menjalankan kegiatan organisasinya;

- hak untuk melakukan kerjasama dalam bentuk federasi atau konfederasi, maupun melakukan afiliasi dengan organisasi-organisasi pekerja pada tingkat internasional;

- hak membuat perjanjian kerja bersama dengan pengusaha; 
- hak mewakili pekerja dalam penyelesaian perselisihan industrial;

- hak mewakili pekerja dalam lembaga ketenagakerjaan.

Dalam praktek, pengaturan penggunaan hak kebebasan berserikat selama ini, menunjukkan adanya ketidakseriusan dalam mengimplemtasikan hak tersebut. Jaminan perlindungan dan penegakan hukum terhadap kebebasan berserikat sebagaimana dimuat dalam berbagai ketentuan perundang-undangan, terkesan adanya ketidak sinkronan antara peraturan yang satu dengan yang lain. Secara substansial hal ini tidak sesuai dengan prinsip mengenai kebebasan berserikat, sebab hak berserikat bagi pekerja sebagaimana diatur dalam pasal 28 UUD 1945 dan Konvensi ILO Nomor 98 tahun 1949 jo. Konvensi ILO Nomor 87 tahun 1948, memberi kebebasan bagi pekerja untuk menggunakan haknya membentuk dan menjadi anggota serikat pekerja, bebas dan bertanggung jawab secara mandiri dan demokratis membentuk organisasi pekerja tanpa harus dipersyaratkan dengan persetujuan pekerja dalam jumlah tertentu.

Hal lain yang bersifat mengurangi kebebasan berserikat bagi pekerja, terutama selama pemerintahan orde baru, ialah dengan tidak diakuinya pendirian serikat pekerja di luar FBSI (SPSI). Pemerintah orde baru pada masa itu, hanya mengakui SPSI sebagai satu-satunya wadah berhimpunnya pekerja dalam bentuk serikat pekerja. Sikap pemerintah yang demikian ini sebenarnya dapat dianggap sebagai pengingkaran terhadap penggunaan kebebasan berserikat. Dengan demikian, jelas bahwa dalam masa pemerintahan orde baru, penggunaan kebebasan berserikat bagi pekerja banyak mengalami hambatan akibat belum adanya kemauan pemerintah, untuk memberi kebebasan kepada pekerja membentuk serikat pekerja secara bebas, mandiri, terbuka dan demokratis tanpa campur tangan pemerintah. 
Terjadinya perubahan pemerintahan sebagai akibat adanya reformasi dalam kehidupan berbangsa dan bernegara, termasuk perubahan di bidang politik dan hukum, membawa perubahan terhadap perkembangan hukum ketenagakerjaan. Perubahan ini secara langsung mempunyai implikasi terhadap penggunaan kebebasan berserikat bagi pekerja, yaitu kebebasan berserikat memperoleh tempat yang wajar. Untuk mendirikan serikat pekerja bebas dari berbagai macam bentuk persyaratan perizinan yang selama orde baru dijadikan sebagai alat untuk menghambat penggunaan kebebasan berserikat bagi pekerja.

Bergulirnya era reformasi dengan tumbangnya pemerintahan Soeharto terdapat puluhan organisasi pekerja di Indonesia dari berbagai aliran idiologi dan jenis pekerjaan. Misalnya ada aliran yang beridiologi agama seperti yang diwakili oleh Persatuan Pekerja Muslim Indonesia (PPMI), Serikat Buruh Muslimin Indonesia (SARBUMUSI) dan sebagainya. Begitu juga yang beraliran nasionalis yang diwakili oleh Serikat Pekerja Seluruh Indonesia (SPSI), Serikat Buruh Kerakyatan (SBK), Serikat Buruh Kartini dan sebagainya. Hal ini menandai hilangnya sifat monolitik organisasi pekerja di Indonesia yang berlangsung selama pemerintahan orde baru yang dikenal sangat otoriter.

Pada satu sisi reformasi politik dan hukum yang terjadi saat ini, telah mendorong terbentuknya iklim yang kondusif tentang penggunaan kebebasan berserikat bagi pekerja melalui pembentukan serikat pekerja di tingkat perusahaan. Namun pada sisi lain, kenyataan menunjukkan bahwa interaksi antara serikat pekerja dengan pengusaha sering tidak berjalan mulus, bahkan dalam banyak hal sering terjadi penekanan-penakanan, baik terhadap pekerja maupun terhadap pengusaha. Hal yang demikian 
menunjukkan tidak mudah memelihara hubungan baik antara pekerja dengan pengusaha. Apabila situasi seperti ini terus berlangsung yang menjadi korban adalah pekerja, akan tetapi bukan mustahil akan mengorbankan jalannya perusahaan.

Salah satu faktor yang menjadi penyebab kurang kondusifnya hubungan antara pekerja dan pengusaha adalah karena terdapat ketidak simbangan antara jumlah tenaga kerja yang tersedia dengan jumlah lapangan pekerjaan, sehingga dengan sendirinya akan terjadi suatu kondisi yang menempatkan tenaga kerja pada posisi yang kurang menguntungkan, karena mereka mengalami kesulitan untuk mendapatkan kesempatan kerja, sedangkan sebaliknya para pengusaha tidak akan mengalami kesulitan untuk mencari tenaga kerja yang sesuai dengan harapannya. Situasi tersebut memberi peluang yang dapat dimanfaatkan oleh pihak pengusaha untuk melakukan penekanan yang mengarah pada eksploitasi tanpa memperhatikan hak-hak pekerja. Perlakuan yang tidak terpuji dari pengusaha itu, tidak jarang mengakibatkan keadaan yang tidak sehat bagi perusahaan, misalnya sering terjadi unjuk rasa dari pekerja yang dapat membuat perusahaan mengalami kerugian karena terhambatnya proses produksi. Bahkan dewasa ini, sering kita mendengar melalui media massa bahwa pekerja melakukan pemogokan karena tidak dipenuhinya tuntutan mereka. Oleh sebab itu penggunaan tenaga kerja oleh pengusaha jangan dijadikan alasan atau dasar untuk mengeksploitasi tenaga mereka, karena bagaimanapun juga pekerja harus dihormati sebagai manusia yang mempunyai harkat dan martabat serta mempunyai hak dan kewajiban.

Segala bentuk tindakan yang tidak sesuai dengan norma-norma yang berlaku di negara Indonesia harus dihindarkan, demi terciptanya kerukunan dan keharmonisan hubungan antara pekerja dan pengusaha 
maupun kerukunan kehidupan berbangsa dan bernegara, hal ini telah digariskan dalam hubungan industrial yang dilandasi oleh nilai-nilai Pancasila. Dapat dikemukakan di sini, bahwa pada dasarnya ide yang terkandung dalam pengertian hubungan industrial yang dilandasi oleh nilainilai Pancasila adalah merupakan hubungan yang menekankan pada asas kekeluargaan dan kemitraan antara pekerja dan pengusaha, dengan tujuan menciptakan iklim berusaha dan bekerja yang tenang. Eksistensi perusahaan dan pekerja tidak dapat dipisahkan satu sama lain, adanya perusahaan pasti menjamin adanya kelanjutan pekerjaan yang dikerjakan oleh pekerja, sebaliknya adanya orang bekerja belum tentu menjamin adanya perusahaan. Oleh sebab itu, perasaan atau sense of belongin harus dimiliki pihak pekerja, sebaliknya pihak pengusaha harus memiliki perasaan sense of humanity, sedangkan bagi keduanya hendaknya sama-sama memiliki perasaan sense of mutual understanding, sense of economics, responsibility dan sense of social responsibility. ${ }^{13}$

Bertolak dari hal yang demikian jika kita memperhatikan prinsip-prinsip dasar yang terdapat dalam hubungan industrial, ada beberapa hal yang perlu mendapat perhatian dan penekanan, antara lain masalah sense of humanity dan sense of mutual understanding. Timbulnya berbagai gejolak yang menyangkut masalah hubungan industrial, pada dasarnya berawal dari tidak adanya atau tidak dimilikinya sense of humanity dari pengusaha. Pengusaha pada umumnya melihat pekerja tidak sebagai mitra untuk memajukan perusahaan tetapi melihat mereka sebagai pihak-pihak yang mempunyai posisi yang rendah. Pemberian upah oleh pengusaha sering kurang memperhatikan kenyataan sosial, bahkan tidak jarang

\footnotetext{
13 Anonim, Simposium Hukum Perburuhan, (Bandung: Bina Cipta, 1977), 122.
} 
pekerja tidak mendapatkan hak-hak mereka. Sering para pekerja mendapat perlakuan yang tidak terpuji dari pengusaha, bahkan terkadang harus mengorbankan nyawa untuk mempejuangkan hak-hak pekerja.

Pada sisi lain yang sering menjadi bibit penyebab terjadinya perselisihan antara pekerja dan pengusaha, adalah kurang berkembangnya sense of mutual understanding. Dalam menetapkan Kesepakatan Kerja Bersama (KKB) sering pihak pekerja menerima perjanjian tersebut karena terpaksa, tidak ada pilihan lain bagi mereka selain menerima isi KKB tersebut. Jika pekerja mencoba menolak tidak tertutup kemungkinan pekerja akan menghadapi Pemutusan Hubungan Kerja (PHK), oleh karena itu perlu diciptakan kondisi yang saling menguntungkan baik bagi pekerja maupun pengusaha. Apabila masalah sense of humanity dan sense of mutual understanding tersebut kurang mendapat perhatian dari pengusaha, maka dampak negatifnya adalah akan muncul unjuk rasa dan pemogokan oleh pekerja. Mereka cenderung melakukannya apabila masalah-masalah hubungan industrial yang mereka hadapi tidak dapat mereka selesaikan sesuai dengan harapan.

Kasus-kasus seperti yang dialami oleh beberapa perusahaan besar di Indonesia, yang melibatkan ribuan buruh mengadakan pemogokan dan unjuk rasa, menggambarkan bahwa masalah hubungan industrial saat ini sarat dengan muatan politis yang dikaitkan dengan isuisu demokrasi dan keterbukaan. Isu-isu ini sering diangkat dan dimanfaatkan untuk mendiskreditkan pengusaha atau kebijakan pemerintah, oleh pihak-pihak tertentu terutama dari kalangan politisi di mana serikat pekerja di perusahaan tersebut berada di bawah kendali atau berafiliasi dengan partainya. Cara yang dilakukan biasanya dengan menyuruh pekerja mogok atau unjuk rasa, kemudian partai yang bersangkutan tampil menawarkan diri sebagai mediator. 
Menurut Archibald $\operatorname{Cok}^{14}$ ada tiga senjata yang dapat digunakan oleh pekerja untuk memperjuangkan hak-hak mereka, ketiga senjata tersebut adalah:

1. Their chief reliance was an a wide variety of arguments, persuation and social pressures aimed at directly at converting workers to the ardent union membership.

2. When this was not enough or when enough emplyers had been organized, but an empolyer refused to recognize the union unions resorted ti strikes, boycotte and picketing.

3. Labor unions also sought the support of public opinion. Their appeal was to intellectuals and reformers of all kinds ...... were synpatetic to the cause of organized labor.

Jadi ketiga senjata yang dimaksud oleh Archibald Cox adalah: aktivitas pekerja dalam serikat pekerja, pemogokan atau boikot dan upaya menarik perhatian intelektual.

Dalam praktek, keaktifan pekerja dalam kegiatan serikat pekerja merupakan senjata yang pertama digunakan untuk memperjuangkan hak-hak pekerja dan untuk mengangkat posisi mereka sejajar dengan pengusaha. Cara-cara yang ditempuh melalui serikat pekerja, biasanya dilakukan dengan mengajukan tuntutan-tuntutan pada pengusaha pada saat merundingkan KKB. Jadi KKB ini merupakan rumusan persyaratan kerja yang dibuat melalui perundingan antara serikat pekerja dengan pengusaha. Ini berarti bahwa Undang-undang Nomor 18 tahun 1956 yang merupakan ratifikasi konvensi ILO Nomor 98 tahun 1949 tentang kebebasan berorganisasi dan berunding bersama, mengandung makna bahwa kebebasan berserikat bagi pekerja disertai pula dengan hak berunding untuk membuat $\mathrm{KKB}$, tujuannya untuk merumuskan syarat-syarat kerja atau

\footnotetext{
${ }^{14}$ Periksa Achibald Cox, at.al. dalam Tjuk Wirawan, "Pengaruh Pelaksanaan Hak Normatif Sosial Ekonomi Buruh Inkonkreto Terhadap Kesejahteraan Buruh Di Perkebunan Kopi Swasta di Jawa Timur". Disertasi, (Surabaya, 1989), 57.
} 
pengaturan hak dan kewajiban yang tidak diatur di dalam peraturan perundang-undangan.

Pemogokan sebagi senjata kedua untuk memperjuangkan hak-hak pekerja, timbul karena tersumbatnya komunikasi diantara pekerja dengan pengusaha. Akibatnya muncul rasa ketidakpuasan terhadap pengusaha berkenaan dengan hak-haknya sebagai pekerja. Di Indonesia hak untuk mogok dijamin di dalam UndangKetenagakerjaan. Hak mogok digunakan sebagai upaya terakhir apabila diantara serikat pekerja dengan pengusaha tidak terdapat kesepakatan, sedang pekerja tidak melihat jalan lain untuk mewujudkan tuntutannya. Dari sudut pandang yang demikian ini dapat ditafsirkan bahwa hak mogok merupakan hak yang tidak dapat dipisahkan dan dianggap selalu melekat pada hak berserikat bagi pekerja.

Dalam hubungannya dengan pemogokan sebagai senjata bagi pekerja, jika diamati dengan seksama kondisi obyektif yang dapat menimbulkan kerawanan dalam hubungan industrial saat ini, adalah tingkat emosional dan solidaritas pekerja yang sangat tinggi. Pada dasarnya hal ini muncul karena adanya tuntutan kebutuhan hidup yang terus meningkat, terjadinya kesenjangan sosial ekonomi. Di samping itu, masih kuatnya sifat pengusaha yang kurang mentaati peraturan perundang-undangan dan kuatnya pengaruh link internasional.

\section{Penutup}

Dari apa yang diuraikan di atas dapat disimpulkan bahwa kebebasan berserikat bagi pekerja yang diimplementasikan dalam bentuk serikat pekerja, merupakan alat atau sarana perjuangan hak dan sebagai kekuatan tawar menawar dengan pengusaha dalam perundingan pada saat menetapkan kesepakatan kerja bersama. Ketidakseriusan dan keengganan pengusaha 
menerima kehadiran serikat pekerja dapat menimbulkan potensi konflik antara pekerja dengan pengusaha, apabila konflik ini terjadi pada akhirnya akan mendorong kalangan intelektual untuk memihak pekerja. Cara-cara yang dilakukan pekerja untuk menarik perhatian intelektual sebagai senjata, biasanya diwujudkan dalam bentuk unjuk rasa dan pernyataan solidaritas terhadap sesama pekerja yang mendapat tekanan dan atau perlakuan yang tidak baik dari pengusaha.

Pada sisi lain terlihat penggunaan kebebasan berserikat bagi pekerja yang diwujudkan dalam bentuk serikat pekerja, selain sebagai instrumen perjuangan hak-hak normatif pekerja juga sangat bermanfaat untuk membangun opini masyarakat, terutama dari kalangan intelektual untuk ikut bersimpati pada perjuangan mereka. Dengan demikian dapat ditarik benang merah bahwa hak untuk membentuk dan menjadi anggota serikat pekerja merupakan salah satu bentuk penghormatan terhadap hak asasi manusia.

\section{Daftar Pustaka}

Anonim. Simposium Hukum Perburuhan. Bandung: Bina Cipta, 1977.

Burkens, M.C. et.al. Beginselen van de Democratische Rechtsstaat. T.tt: Tjeenk Willink Zwale, 1990.

Drummond, William F. Social Justice. Milwaukee: The Bruce Publishing Company, 1995.

Kelsen, Hans. Teori Hukum Murni. Bandung: Rindi Press, 1995.

Leander, Victor L. Kamus Belanda Indonesia. Jakarta: Mutiara, 1978.

Macpherson, C.B. Democratic Theory. Oxford: Clerendom Press, 1973.

Mc Golderick, D. The Human Rights Committee. Oxford: Clarendom Press, 1999. 
Mertokusumo, Sudikno. Mengenal Hukum. Yogyakarta: Liberty, 1996.

Meuwissen. Grondrechten. Utrecht: Spectrum, 1984.

Oppenheim, I. International Law. New York: Oxford University Press, 1947.

Paton, G.W. A Tex Book of Jurisprudence. London: Oxford at the Clarendom Press, 1955.

Radbruch dan Dabin. The Legal Philosophi. New York: Harvard University Press, 1950.

Sieghart, Paul. The Lawfull Rights of Mankind, an Introduction to the International Legal Code of Human Rights. New York: Oxford University Press, 1986.

Starke, J.G. An Introduction to International Law. Berkley and Los Angles: University of California, 1954.

Wirawan, Tjuk. "Pengaruh Pelaksanaan Hak Normatif Sosial Ekonomi Buruh Inkonkreto terhadap Kesejahteraan Buruh di Perkebunan Kopi Swasta di Jawa Timur". Disertasi. Surabaya. 1989. 